DOI 10.14746/ppuam.2017.7.14

Artur Szmigielski

\title{
Sector Inquiry into Cross-Border E-Commerce: the Challenges and Practical Implications for European Union Completion Law
}

\section{Introduction}

On 6 May 2015, the European Commission launched a competition inquiry into the European Union's ${ }^{1}$ e-commerce sector. ${ }^{2}$ As such, the investigation should be seen in the context of the Commission's wider digital enforcement and policy agenda, especially the Digital Single Market Strategy, ${ }^{3}$ which is a key priority for the Juncker Commission. The sector inquiry will focus on identifying and addressing private and - in particular - contractual barriers to cross-border online commerce in digital content and sales of goods. ${ }^{4}$ As the Commission states, in 2014, half of all EU consumers shopped online, but only around $15 \%$ bought something from a seller based in another EU Member State. ${ }^{5}$

Commissioner Vestager highlighted a number of factors that may currently be limiting cross-border e-commerce: language barriers and different national consumer preferences; differences in legislation across Member States; technical barriers erected by companies, such as geo-blocking, which restrict cross-border online sales by preventing consumers from accessing certain websites on the basis of their residence or credit card

1 Hereinafter: EU or Union.

2 V. the Commission Decision of 6 May 2015 initiating an inquiry into the e-commerce sector pursuant to Article 17 of Council Regulation (EC) no. 1/2003, C(2015) 3026 final. For the purpose of this decision, the e-commerce sector is defined as the online trade of goods and the online provision of services.

3 Communication from the Commission of 6 May 2015 to the European Parliament, the Council, the European Economic and Social Committee and the Committee of the Regions, A Digital Single Market Strategy for Europe, COM(2015) 192 final (hereinafter: DSM Strategy).

4 Commissioner Vestager stated that she will formally propose the inquiry to the wider Commission also in May and - on the expectation that it is endorsed - aim to publish the preliminary findings by the middle of 2016. Previous sector inquiries have taken around 18 months to two years to conclude. Given the complex markets involved and the diversity of participants, it is to be expected that this inquiry, too, will last at least as long.

5 Press release of 6 May 2015, Antitrust: Commission launches e-commerce sector inquiry, IP/15/4921. 
details; and restrictions that are the result of agreements between manufacturers and content owners on the one hand, and their distributors on the other. Therefore, it is believed that businesses may themselves establish barriers to cross-border online trade, with a view to fragmenting the internal market along national borders and preventing competition. ${ }^{6}$

The aim of this article is to show what the practical implications are regarding this investigation, in the context of a general integration objective - creating an internal market comprising all the territories of the EU member states, in which national borders are no longer an obstacle to commerce. ${ }^{7}$ Because of their specific and dynamic nature, the application of competition law to online markets may prove challenging. Therefore, the focus will also be directed to challenges that could be faced when anti-competitive practices in the e-commerce sector will be strictly enforced. The question is whether traditional competition analysis may be sufficiently able to reflect the way in which competition takes place on digital markets.

\section{The legal context of the EU sector inquiry}

\section{What is a sector inquiry?}

The sector inquiry launched by the Commission is regulated by Article 17 of the Council Regulation on the implementation of the rules on competition laid down in Articles 81 and 82 of the Treaty. ${ }^{8}$ Under this provision, the Commission may conduct its inquiry into a particular sector of the economy or into a particular type of agreement across various sectors, when it suspects that competition may be restricted or distorted within the common market. Therefore, a sector inquiry as such is a general investigation that is carried out by the European Commission into those sectors of the economy where it believes competition may not be working effectively. They are comparatively rare, because before the current e-commerce sector inquiry, the last one was launched in January 2008 to investigate the EU pharmaceuticals industry. However, they are suitable for looking at markets that are rapidly evolving, and at where the future competitive environment will be shaped by a commercial framework that is already in place but whose effects are not fully understood. It is worth noting that there is no need for the Commission to

6 Commissioner Vestager's speech of 26 March 2015, Competition policy for the Digital Single Market: Focus on e-commerce, SPEECH/15/4704.

7 The Court of Justice of European Union (hereinafter: CJEU or Court) defined the internal market as transnational market operating under conditions similar to an internal - i.e. national - market. V. Case 159/78, Commission v. Italy [1979], EU: C:1979:243.

8 Council Regulation (EC) no. 1/2003 of 16 December 2002 on the implementation of the rules on competition laid down in Articles 81 and 82 of the Treaty, OJ L 1, pp. 1-25 (hereinafter: Regulation 1/2003). 
have evidence of an infringement of an EU competition law before commencing a sector inquiry. ${ }^{9}$

\section{What are the Commission's Powers when Conducting Sector Inquiries?}

The Commission has wide-ranging investigatory powers in the context of an inquiry. In practice, at least initially, the Commission has tended to engage in dialogue with, and address questionnaires to, the various stakeholders in the sector under investigation. The Commission could request extensive information relating to market structure, customers, distribution and supply agreements, and commercially sensitive economic and pricing information, as well as background information on the relevant national legislative and regulatory frameworks. The Commission typically issues a voluntary request in the first instance. However, if a company does not voluntarily reply to questions, then the Commission has the ability to order it to do so. The Commission's powers in that respect are broadly comparable to those it has in a cartel investigation, including the ability to fine respondents for supplying incorrect, incomplete or misleading information. Of course, the Commission is legally obliged to state the legal basis and the purpose of the request for information, specify what information it is requesting, and set the time limit within which the information must be provided. ${ }^{10}$

What is more, the Commission may authorise specific persons to enter any premises, property, or means of transport; examine and take copies of the books and other records related to the business; seal the premises and the materials under inspection; and ask questions to the representatives or staff of the companies or associations under inspection, and record their answers. The companies and associations concerned have the duty to submit to the inspection ordered by the Commission. It is important that the companies' commercially sensitive information, which has been collected by the Commission during the course of a sector inquiry, will be kept confidential. ${ }^{11}$

\section{The Commission's review of the perceived company-erected barriers}

\section{An integrational objective of EU competition law and geo-blocking}

According to Roberta Bork: "Antitrust policy cannot be made rational until we are able to give a firm answer to one question: what is the point of the law - what are its

9 M. Timothy, A. Pomana, A.M. Heemsoth, European Competition Commissioner announces proposed sector inquiry into cross-border e-commerce, "European Competition Law Review" 2015, vol. 36 , no. 9 , p. 367.

10 Article 18(2) Regulation 1/2003.

11 Article 28 Regulation 1/2003. 
goals?"12 European Union competition law is based not just on economic aspects (consumer welfare), but also on the policy objectives of European integration. In particular, EU competition policy is strongly influenced by the goal of creating an internal market comprising all the territories of the EU Member States, in which national borders are no longer an obstacle for commerce. ${ }^{13}$ Indeed, private barriers to trade and competition would risk replacing the public barriers to free movement that have already been dismantled. ${ }^{14}$

As far as economic efficiency is concerned, the e-commerce sector has been growing for years and continues to grow. In the literature, by way of illustration, it is noted that "in the USA, the total revenue deriving from e-commerce sales in business-to-business trade alone was USD 5.4 trillion in 2012. In Europe, it has been estimated that in 2013, $14 \%$ of the revenue of EU companies with ten or more employees was generated from ecommerce."15 The Commission expects that a properly functioning digital market could increase the EU's gross domestic product by EUR 315 billion. ${ }^{16}$ This may partly explain the economic rationale for the sector inquiry, but it is not only reason in terms of EU competition goals.

The Internet boosts cross-border commerce between Member States and thereby enhances the functioning of an internal market. As is pointed out in the relevant literature, in online markets the role of the physical distance between consumers and the place where digital content is made available to the public has sharply diminished. ${ }^{17}$ The oftcited catch-phrase claims anything is "just one click away" - no geographical barriers seem to exist in electronic trade. ${ }^{18}$ This is not only due to the enhanced communication channel, but also to the drop in costs faced by businesses, which are now able to serve larger geographical markets. In this context, distance can be interpreted only as a measure of cultural difference between countries and as preference for cultural proximity. ${ }^{19}$

12 R.H. Bork, The Antitrust Paradox: A Policy at War with Itself, Oxford 1997, p. 50.

13 T.G. Funke, Territorial Restraints and Distribution in the European Union, Distribution and Franchising Committee: ABA Section of Antitrust Law, September 2013, p. 3.

14 D.J. Gerber, Law and the Abuse of Economic Power in Europe, "Tulane Law Review"1987, no. 62, p. 85.

15 F. Carloni, S. S. Megregian, M. Bruneau, The E-Commerce Sector Inquiry: Can It Stop National Competition Authorities from Adopting an Overly Restrictive Approach?, "European Competition Law Review" 2015, vol. 6, no. 9, p. 643.

16 Press release of 6 May 2015, IP/15/4921.

17 See, e.g., G. Mazziotti, Is geo-blocking a real cause for concern in Europe?, EUI Working Paper, Italy 2015, p. 9.

18 Cf. K. Kohutek, Rynki wyszukiwarek internetowych a zarzut nadużycia pozycji dominujacej (na tle unijnej sprawy przeciwko Google), "Europejski Przegląd Sądowy” 2014, no. 10, p. 35.

19 E. Gomez, B. Martens, Language, Copyright and Geographic Segmentation in the EU Digital Single Market for Music and Film, European Commission, Joint Research Centre,JRC Technical Reports (2015), p. 12. 
Therefore, the Internet is believed to have substantial pro-competitive effects that can enhance consumer welfare.

However, in the EU, although more and more goods and services are traded over the Internet, cross-border online sales within the EU are only growing slowly. Cultural differences are not the only issue, because, as was pointed out above, business may themselves establish barriers to cross-border online trade. According to the Commission, such perceived barriers could result in the territorial fragmentation of the EU single market and the restriction of price competition. ${ }^{20}$ The Commission's contention regarding the perceived company-erected barriers relies on the findings of the studies, according to which:

- $32 \%$ of retailers mentioned contractual restrictions in their distribution agreements as the reason for refusing to supply cross-border services, ${ }^{21}$

- 19.1\% of companies currently active in cross border e-commerce and $29 \%$ of companies that are not yet active stated that "suppliers' restrictions affecting sales on online platforms constituted or would constitute a problem for their business when selling online."22

The Commission proposes to outlaw "unjustified" geo-blocking, which refers to practices used for commercial reasons involving online sellers either denying consumers access to a website based on their location, or re-routing them to a local website with different prices. Such blocking means that different prices can be applied on the basis of geographic location. In effect businesses are prohibited from providing different prices, products or services on the basis of a consumer's location unless restrictions on supply or price can be justified by specific laws. ${ }^{23}$ This can be illustrated by the Commission's investigations, which will be described in the subsequent sections of this article.

\section{The Murphy (Premier League) case}

As regards trade in digital content, the Commission referred to the Court of Justice of the European Union's ruling in Murphy ${ }^{24}$ as the leading precedent. In Murphy, the Football Association Premier League granted broadcasters the exclusive live broadcasting rights for Premier League matches in the UK and for 3-year terms. In order to protect the territorial exclusivity of each broadcaster, all the broadcasters undertook in the license agreement to prevent the public from receiving their broadcasts outside the

20 Press release of 6 May 2015, IP/15/4921.

21 ECC Net report on the application of Articles 20.2 and 21 of the Services Directive, 2013.

22 Flash Eurobarometer 413; the studies are cited in the Commission's Fact Sheet of 6 May 2015, Antitrust: Commission launches e-commerce sector inquiry, MEMO/15/4922.

23 DSM Strategy, § 2.3.

24 Joined cases C-403/08 and C-429/08, Murphy [2011], EU:C:2011:631 (hereinafter: Case Murphy). 
licensed territory (i.e. another Member State). In particular, the broadcasters had to ensure that all broadcasts that could be received outside their territory - in particular those transmitted by satellite - were securely encrypted and were prohibited from supplying decoding devices giving access to the football matches if they were used outside their licensed territory. Under these contractual restrictions, broadcasters issued decoder cards subject to the condition that customers did not use them outside the territory of that broadcaster.

As a result, absolute territorial protection was afforded to the broadcasters as television viewers were prevented from accessing and watching matches broadcast by broadcasters established outside of the Member State where they resided. The CJEU concluded that these restrictions were unjustifiable. It took the view that agreements partitioning national markets and rendering the inter-penetration of national markets more difficult may frustrate the Treaty's objective of achieving the integration of those markets through the establishment of a single market. The Courts refer to this objective as the single market imperative. On this basis, the agreements must be regarded, in principle, as those whose object is to restrict competition within the meaning of Article 101(1) of the Treaty on the Functioning of the European Union (hereinafter: TFEU). ${ }^{25}$

\section{Pay-TV investigation}

In January 2014 the European Commission announced that it is conducting an investigation into licensing agreements between major film studios and Pay-TV broadcasters. ${ }^{26}$ Audiovisual content, such as popular sports coverage and films, is licensed by rights holders to Pay-TV broadcasters on an exclusive and territorial basis, i.e. typically to a single Pay-TV broadcaster in each Member State. As a result of its findings, the Commission has opened formal antitrust proceedings to examine certain provisions in licensing agreements between several major US film studios (Twentieth Century Fox, Warner Bros., Sony Pictures, NBC Universal, Paramount Pictures) and the largest European Pay-TV broadcasters such as BSkyB of the UK, Canal Plus of France, Sky Italia of Italy, Sky Deutschland of Germany, and DTS of Spain. The investigation, as the Commission has been keen to point out, does not call into question the possibility to grant licenses on a territorial basis, or try to oblige studios to sell rights on a pan-European basis. However, the Commission is concerned that the licensing arrangements continue to grant Pay-TV broadcasters absolute territorial protection which ensures that the films licensed by the major studios are shown exclusively in the Member State where each broadcaster operates via satellite and the Internet. According to the Commission, films cannot be made available outside that Member State, even in response to unsolicited requests from

25 Case Murphy, § 139.

26 Press release of 23 July 2015, Antitrust: Commission sends Statement of Objections on cross-border provision of pay-TV services available in UK and Ireland, IP/15/5432. 
potential subscribers in other Member States. ${ }^{27}$ Such arrangements may constitute an infringement of EU antitrust rules that prohibit anti-competitive agreements. While the focus of the current investigation is on the major film studios, the case will be watched closely by the European film industry. To this extent, cultural considerations are likely to form a key part of the Commission's assessment of the licensing arrangements. ${ }^{28}$

If this antitrust initiative were successful, the liberalisation of online passive sales might become the "Trojan horse" through which the Commission would reform copyright laws and eventually revisit its principle of territoriality. ${ }^{29}$ Significantly, the Premier League judgment and this investigation have shown that the application of EU competition law in digital settings might trigger unexpected consequences for territorial licensing, therefore, significantly erode the Coditel II principles. $^{30}$

\section{Restrictions on online sales in distribution agreements}

\section{General consideration}

The Commission states that EU competition rules applicable to vertical restrictions are the same for offline and online sales. Although this statement is obviously true, in a superficial sense, the way in which rules and principles can be adapted to online sales leaves many crucial issues open. The Vertical Agreements Block Exemption Regulation (hereinafter: VABER) provides a safe harbour for most vertical agreements, ${ }^{31}$ to the extent that such agreements contain vertical restraints. The VABER provides that the prohibition in Article 101 TFEU does not apply to vertical agreements between undertakings with market shares not exceeding 30\%. ${ }^{32}$ However, if a vertical agreement contains any of the so-called hardcore restriction listed in the VABER, the entire agreement ceases to benefit from the VABER, and Article 101 TFEU applies directly to the agreement. The most important examples of hardcore restrictions are resale price maintenance (RPM) and restrictions on the territory into which, or the customers to whom, a distributor

\section{Ibidem.}

28 B. Keane, The Application of Competition Law in the Entertainment and Sport Sectors, "Journal of European Competition Law \& Practice” 2014, vol. 5, no. 8, pp. 592-593.

29 I. Colomo, Copyright reform through competition law? The Commission's statement of objections in the pay TV investigation, Chillin' Competition, 24.07.2015.

30 Based on the classic distinction between the existence and the exercise of copyright, the Court made it clear that a licensing/distribution agreement containing an exclusivity clause for a given territory during a specified period did not, as such, infringe Article 101(1) TFEU. V. Case 262/81, Coditel II [1982], EU: C:1982:334.

31 Commission Regulation (EU) no. 330/2010 of 20 April 2010 on the application of Article 101(3) of the Treaty on the Functioning of the European Union to categories of vertical agreements and concerted practices, OJ L 102, pp.1-7.

32 Article 3 VABER. 
may sell. ${ }^{33}$ Restrictions that are classified as hardcore by the VABER will generally be found to be 'by object' restrictions in an individual assessment under Article 101 TFEU. 'By object' restrictions are defined as those which, in the light of the objectives pursued by the Union competition rules, are so likely to have negative effects on competition, in particular on the price, quantity, or quality of goods or services, that it is unnecessary to demonstrate any actual or likely anticompetitive effects on the market. ${ }^{34}$ Agreements containing a 'by object' restriction are almost always null and void and, if found, are, as a rule, prohibited, with a high likelihood that the authority will impose a fine. There has been debate about whether the VABER and the Guidelines ${ }^{35}$ adequately cover on-line sales. In particular, there has been discussion about the extent to which suppliers may restrict on-line sales within their selective distribution systems, ${ }^{36}$ and whether such restrictions should be classified as hardcore.

One could state that restrictions of online sales should not be allowed, as the Internet is now an essential means of reaching customers - it reduces costs, enhances competition, and facilitates cross-border trade. ${ }^{37}$ On the other hand, some manufacturers in particular argued that it is important that they should be allowed, within their selective distribution systems, to set rules for the use of the Internet. They emphasised that competition can take place over parameters other than price, such as after-sales services, quality and brand. Unrestricted on-line sales may increase the risk of counterfeiting and free-riding on certain distributors' sales efforts and may dampen suppliers' incentives to innovate, invest and increase productivity, which could harm the EU's competitiveness. ${ }^{38}$

The Commission assessed and evaluated both sets of arguments and drew conclusions with the aim of protecting competition and consumers. On the one hand, it made clear in the Guidelines that online sales are very important for reaching certain customers - "the Internet is a powerful tool to reach a greater number and variety of customers than by more traditional sales methods." ${ }^{39}$ Therefore, the Commission found that certain - but not all - restrictions on the use of the Internet should be considered hardcore

33 Article 4 VABER.

34 Commission Staff Working Document of 25 June 2014, Guidance on restrictions of competition "by object" for the purpose of defining which agreements may benefit from the De Minimis Notice, SWD (2014) 198 final.

35 Commission Guidelines on Vertical Restraints, OJ C 130, p.1 (hereinafter: Vertical Guidelines).

36 J. Hederström, L. Peeperkorn, Vertical Restraints in On-line Sales: Comments on Some Recent Developments, "Journal of European Competition Law \& Practice" 2016, vol. 7, no. 1, pp. 10-23.

37 The literature on e-commerce has mainly reviewed four issues: (i) search costs, (ii) how e-commerce affects the geographic scope of transactions, (iii) the distribution cost and (iv) how e-commerce affects the existence of information asymmetries between consumers and suppliers.

38 OECD, Vertical Restraints for On-line Sales 2013, DAF/COMP (2013) 13, p. 5.

39 Vertical Guidelines, § 52 . 
resale restrictions under Article 4(b) and/or (c) of the VABER40. On the other hand, the Commission recognised the potential problems of free-riding and the potential of vertical restraints to help achieve efficiencies in the interest of consumers. ${ }^{41}$

Lastly, the VABER and the Guidelines are based on the principle that the same rules should apply, irrespective of whether sales take place offline or on-line, not least because many transactions are in practice a mix of online and offline sales and purchase activities. This means that to the extent that suppliers are allowed under the VABER and the Guidelines to give instructions to their distributors on how their products are to be sold offline, the same approach should apply to online sales. ${ }^{42}$

\section{Examples of restrictions on Internet sales}

Competition authorities and courts have already dealt with a significant number of vertical restraints imposed on online sales by suppliers who adopted a selective distribution system. These cases mostly concern products that can be qualified as luxury, experience, or credence goods. The case law can be presented by delineating three sets according to the type of restrictions examined: the first identifies those restrictions that are generally considered compatible with antitrust rule - soft regulations; the second set includes those restrictions that raise serious doubts - strong regulations; and the third set relates to the general ban of Internet trade and other extreme regulations. ${ }^{43}$

As far as soft regulations are concerned, competition authorities have clarified that a supplier can legitimately impose quality standards for e-commerce on its appointed dealers. ${ }^{44}$ These quality standards may refer to the graphical and text content of the website, the delivery time, the return policy, the provision of means through which customers can obtain advice, the stock of products that must be made available to buyers,

40 Therefore, in principle, every distributor must be allowed to use the Internet to sell products. V. Vertical Guildness, $§ 52$.

41 For many products, Internet sales can free ride off of the promotional effort exerted by brick and mortar retailers, leading manufacturers to attempt to control the availability and pricing of their products over the Internet. V.W.D. Carlton, J. A. Chevalier, Free riding and sales strategies for the Internet, "Journal of Industrial Economics" 2001, vol. 49, no. 4, pp. 441-461.

42 The Commission explains that it does not mean that the criteria imposed for online sales must be identical to those imposed for offline sales, but rather that they should pursue the same objectives and achieve comparable results, and that the difference between the criteria must be justified by the different nature of these two distribution modes. V. Vertical Guidelines, § 56.

43 P. Buccirossi, Vertical restraints on e-commerce in the case of selective distribution, "Journal of Competition Law \& Economics" 2015, vol.11, no. 4, p. 764.

44 Therefore, under the VABER the supplier may require quality standards for the use of the Internet site to resell its goods, just as the supplier may require quality standards for a shop or for selling by catalogue, or for advertising and promotion in general. This may be relevant in particular for selective distribution. V. Vertical Guidelines, $§ 54$. 
and the like. ${ }^{45}$ The conditions determined by these standards must be equivalent to those imposed on physical stores and cannot imply obligations "which dissuade appointed dealers from using the Internet to reach a greater number and variety of customers." ${ }^{46}$

In terms of strong regulations, a frequently discussed example of a restriction of online sales is the general prohibition for dealers participating in a selective distribution system to use independent marketplace platforms. This restriction is currently being implemented by a vast number of manufacturers of branded goods. ${ }^{47}$ In some cases this prohibition on using independent marketplace platforms even applies if a marketplace platform is fully integrated into the online offer of an internet dealer who is also a member of a selective distribution system. As the Commission states, suppliers may require that customers do not visit the website of a retailer through a site carrying the name or logo of a third party platform, as is usually the case for such marketplace platforms. ${ }^{48}$ Consequently, such a prohibition is not regarded as a hardcore restriction by the Commission. This is a view that is also often shared in the literature, in particular with regard to the prohibition of online auctioning platforms. ${ }^{49}$ However, the case law has been ambiguous in this matter. For instance, The German Federal Cartel Office (Bundeskartellamt) and the Schleswig Court of Appeals (Oberlandesgericht) have held that the highly-renowned brands Adidas, ASICS and Casio must allow their approved resellers to use Internet auction sites and online marketplaces to resell their goods. ${ }^{50}$

According to the decision of the CJEU in the Pierre Fabre case, a contract clause prohibiting de facto the use of the Internet as a marketing method "at the very least has as its object the restriction of passive sales to end users wishing to purchase online and located outside the physical trading area of the relevant member of the selective distribution system." ${ }^{11}$ An individual exemption under Article 101(3) TFEU remains possible. In order to obtain this, the companies would have to explain to what extent the criteria listed under Article 101(3) TFEU are cumulatively satisfied: in the case of a total prohibition of internet sales, even if there are efficiency gains, it will be difficult to prove that the restriction is indispensable and that consumers have been granted a fair share of the benefits. $^{52}$

45 V., e.g., Conseil de la Concurrence, Décision no. 07-D-07 du 8 mars 2007 relative à despratiques mises en oeuvre dans le secteur de la distribution des produits cosmétiques etd'hygiène corporelle, http://www.autoritedelaconcurrence.fr/pdf/avis/07d07.pdf [access: 2.03.2017].

46 Vertical Guidelines, § 56.

47 Bundeskartellamt, Vertical Restraints in the Internet Economy, Meeting of the Working Group on Competition Law, Bonn 2013, p. 22.

48 Vertical Guidelines, $§ 54$.

49 Bundeskartellamt, op. cit., p. 22.

50 Press Release of 28 April 2014, Bundeskartellamt takes a critical view of restriction of online distribution by ASICS.

51 Case C-439/09, Pierre Fabre [2011], EU: C:2011: 649.

52 Bundeskartellamt, op. cit., pp. 21-22. 
Other extreme regulations, which are considered to be hardcore restrictions, include the following restrictions: (1) preventing customers located in another (exclusive) territory from viewing a website or automatically re-routing customers to the manufacturer's or other (exclusive) distributors' websites, (2) terminating consumers' transactions over the Internet once their credit card data reveal an address that is not within the distributor's (exclusive) territory, (3) limiting distributors' proportion of overall sales made over the Internet (requiring a minimum turnover from offline sales would be legitimate, which implies that it is equally legitimate to exclude pure online distributors from the manufacturer's distribution network), and (4) imposing higher wholesale prices for products intended to be resold by the distributor online than for products intended to be resold offline. ${ }^{53}$

\section{Conclusions}

Information gained through sector inquiries could inevitably inform the legislative process in that market. This is especially true for a sector inquiry such as e-commerce, which concerns one of the key pillars of the Commission's 2020 Agenda: achieving a digital single market. Sector inquiries also often form the basis of major enforcement actions. Where the Commission finds competition infringements in the investigated sector, it will subsequently conduct specific investigations into individual market participants. ${ }^{54}$

A wide-ranging antitrust inquiry will involve hundreds of suppliers, content owners and online resellers. The focus is electronics, clothing and shoes, as well as digital content..$^{55}$ The first mandatory requests for information have been received. They seek information on allegedly illegal practices to restrict online sale of products and content via contractual means, discriminatory pricing or technical geo-blocking measures. The sector inquiry could well lead to specific prosecutions of companies found to have engaged in illegal restrictions on online sales. Officials have stated privately that at minimum the output of the sector inquiry is likely to lead to changes to the rules on online distribution, as set out in the Vertical Restraints Guidelines. Fierce lobbying can be expected on the rules according to which suppliers can restrict products to appointed dealers under a "selective distribution system" and whether they are permitted to exclude certain retailers. ${ }^{56}$

53 Vertical Guidelines, $§ 52$.

54 B. Batchelor, B. Allgrove, M. Agnew, Digital disruption: the practical implications of the EU's Digital Single Market agenda, "European Competition Law Review"2015, vol. 36, no. 9, p. 379. $55 \mathrm{http}: / /$ ec.europa.eu/competition/antitrust/sector_inquiries_e_commerce.html.

56 B. Batchelor, op. cit., p. 379. 
246 | Adam Mickiewicz University Law Review

\section{Literature}

Batchelor B., Allgrove B., Agnew M., Digital disruption: the practical implications of the EU's Digital Single Market agenda, "European Competition Law Review" 2015, vol. 36, no. 9 .

Bork R. H., The Antitrust Paradox: A Policy at War with Itself, Oxford 1997.

Buccirossi P., Vertical restraints on e-commerce in the case of selective distribution, "Journal of Competition Law \& Economics" 2015, vol.11, no. 4.

Bundeskartellamt, Vertical Restraints in the Internet Economy, Meeting of the Working Group on Competition Law, Bonn 2013.

Carloni F., Megregian S.S., Bruneau M., The E-Commerce Sector Inquiry: Can It Stop National Competition Authorities from Adopting an Overly Restrictive Approach?, "European Competition Law Review" 2015, vol. 6, no. 9.

Carlton W.D., Chevalier J.A., Free riding and sales strategies for the Internet, "Journal of Industrial Economics" 2001, vol. 49, no. 4.

Case 159/78, Commission v. Italy [1979], EU: C:1979:243.

Case 262/81, Coditel II [1982], EU: C:1982:334.

Case C-439/09, Pierre Fabre [2011], EU: C:2011:649.

Colomo I., Copyright reform through competition law? The Commission's statement of objections in the pay TV investigation, Chillin' Competition, 24.07.2015.

Commission Decision of 6 May 2015 initiating an inquiry into the e-commerce sector pursuant to Article 17 of Council Regulation (EC) no. 1/2003, C (2015) 3026 final.

Commission Guidelines on Vertical Restraints, OJ C 130.

Commission Regulation (EU) No 330/2010 of 20 April 2010 on the application of Article 101(3) of the Treaty on the Functioning of the European Union to categories of vertical agreements and concerted practices, OJ L 102.

Commission Staff Working Document of 25 June 2014, Guidance on restrictions of competition "by object" for the purpose of defining which agreements may benefit from the De Minimis Notice, SWD (2014) 198 final.

Commission's Fact Sheet of 6 May 2015, Antitrust: Commission launches e-commerce sector inquiry, MEMO/15/4922.

Commissioner Vestager's speech of 26 March 2015, Competition policy for the Digital Single Market: Focus on e-commerce, SPEECH/15/4704.

Communication from the Commission of 6 May 2015 to the European Parliament, the Council, the European Economic and Social Committee and the Committee of the Regions, A Digital Single Market Strategy for Europe, COM (2015) 192 final.

Conseil de la Concurrence, Décision no. 07-D-07 du 8 mars 2007 relative à despratiques mises en oeuvre dans le secteur de la distribution des produits cosmétiques et d'hygiène corporelle, http://www.autoritedelaconcurrence.fr/pdf/avis/07d07.pdf [access: 2.03.2017]. 
Council Regulation (EC) no. 1/2003 of 16 December 2002 on the implementation of the rules on competition laid down in Articles 81 and 82 of the Treaty, OJ L 1.

ECC Net report on the application of Articles 20.2 and 21 of the Services Directive, 2013.

Funke T.G., Territorial Restraints and Distribution in the European Union, Distribution and Franchising Committee: ABA Section of Antitrust Law, September 2013.

Gerber D. J., Law and the Abuse of Economic Power in Europe, "Tulane Law Review"1987, no. 62 .

Gomez E., Martens B., Language, Copyright and Geographic Segmentation in the EU Digital Single Market for Music and Film, European Commission, Joint Research Centre, JRC Technical Reports (2015).

Hederström J., Peeperkorn L., Vertical Restraints in On-line Sales: Comments on Some Recent Developments, "Journal of European Competition Law \& Practice” 2016, vol. 7, no. 1.

Joined cases C-403/08 and C-429/08, Murphy [2011], EU: C:2011:631.

Keane B., The Application of Competition Law in the Entertainment and Sport Sectors, "Journal of European Competition Law \& Practice" 2014, vol. 5, no. 8.

Kohutek K., Rynki wyszukiwarek internetowych a zarzut nadużycia pozycji dominujacej (na tle unijnej sprawy przeciwko Google), "Europejski Przegląd Sądowy” 2014, no. 10.

Mazziotti G., Is geo-blocking a real cause for concern in Europe?, EUI Working Paper, Italy 2015.

OECD, Vertical Restraints for On-line Sales 2013, DAF/COMP (2013) 13.

Press release of 6 May 2015, Antitrust: Commission launches e-commerce sector inquiry, IP/ 15/4921.

Press release of 23 July 2015, Antitrust: Commission sends Statement of Objections on crossborder provision of pay-TV services available in UK and Ireland, IP/15/5432.

Press release of 28 April 2014, Bundeskartellamt takes a critical view of restriction of online distribution by ASICS.

Timothy M., Pomana A., Heemsoth A.M., European Competition Commissioner announces proposed sector inquiry into cross-border e-commerce, "European Competition Law Review" 2015, vol.36, no. 9.

\section{SUMMARY}

\section{Sector Inquiry into Cross-Border E-Commerce: Challenges and Practical} Implications for European Union Completion Law

The aim of this article is to show what the practical implications are regarding the Commission inquiry into e-commerce sector launched on 6 May 2015. Because of their spe- 
248 | Adam Mickiewicz University Law Review

cific and dynamic nature, the application of competition law to online markets may prove challenging. Therefore, the focus will be also directed to challenges that could be faced when anti-competitive practices in e-commerce sector are strictly enforced. The question is whether traditional competition analysis may be sufficiently able to reflect the way in which competition takes place on digital markets.

Keywords: EU competition law, e-commerce, sector inquiry, selective distribution, geoblocking

Artur Szmigiels ki, University of Warsaw, Faculty of Law and Administration, Krakowskie Przedmieście 26/28, 00-927 Warszawa, Republic of Poland, e-mail: artur.szmigielski@wpia.uw.edu.pl. 